\title{
Mineralogical Evolution of the Cretaceous Strata in the Songliao Basin, Northeastern China: Implications for Thermal History and Paleoenvironmental Evolution
}

\author{
Tian Dong ${ }^{1}$, Yuan Gao ${ }^{1,2, *} \mathbb{D}$, He Huang ${ }^{1,2}$, Xing Tian ${ }^{1,2}$, Qian Yang ${ }^{1}$, Yuyin $\mathrm{Li}^{1}{ }^{1}$, Lu Niu ${ }^{1}$ and Yongqiang Cao ${ }^{1}$ \\ 1 State Key Laboratory of Biogeology and Environmental Geology, China University of Geosciences (Beijing), \\ Beijing 100083, China; tiandong@cugb.edu.cn (T.D.); huang1006@cugb.edu.cn (H.H.); \\ tianxing@cugb.edu.cn (X.T.); 2101200045@cugb.edu.cn (Q.Y.); liyuyin@cugb.edu.cn (Y.L.); \\ 2101190028@cugb.edu.cn (L.N.); 2101200119@cugb.edu.cn (Y.C.) \\ 2 School of Earth Science and Resources, China University of Geosciences (Beijing), Beijing 100083, China \\ * Correspondence: yuangao@cugb.edu.cn
}

check for updates

Citation: Dong, T.; Gao, Y.; Huang, H.; Tian, X.; Yang, Q.; Li, Y.; Niu, L.; Cao, Y. Mineralogical Evolution of the Cretaceous Strata in the Songliao Basin, Northeastern China: Implications for Thermal History and Paleoenvironmental Evolution. Minerals 2021, 11, 1101. https:// doi.org/10.3390/min11101101

Academic Editor: Luca Aldega

Received: 30 July 2021

Accepted: 5 October 2021

Published: 8 October 2021

Publisher's Note: MDPI stays neutral with regard to jurisdictional claims in published maps and institutional affiliations.

Copyright: (c) 2021 by the authors. Licensee MDPI, Basel, Switzerland. This article is an open access article distributed under the terms and conditions of the Creative Commons Attribution (CC BY) license (https:/ / creativecommons.org/licenses/by/ $4.0 /)$.

\begin{abstract}
The Songliao Basin in northeastern China is one of the largest and longest-lived Cretaceous sedimentary basins enriched in petroleum and geothermal resources worldwide. Although the modern Songliao Basin has a high geothermal gradient, the geological thermal history of the basin has not been well constrained. The SK-2 drilling program, as the second stage of the International Continental Drilling Project of Cretaceous Songliao Basin, is for recovering extensive Early Cretaceous terrestrial strata and providing valuable materials for decoding the mineralogical evolution and the paleoenvironmental changes. Here, we present whole-rock and clay mineralogical analysis on 72 core samples covering 3346-5705 m of the Shahezi Formation in the SK-2 borehole. The wholerock minerals mainly include clay minerals, quartz, plagioclase, as well as some calcite, K-feldspar, siderite, and pyrite. The clay mineral assemblages include illite, chlorite, and illite-smectite interlayer minerals. Above $4500 \mathrm{~m}$, clay minerals are dominated by illite and illite-smectite interlayers. Below $4500 \mathrm{~m}$, more plagioclase, K-feldspar, and calcite are present, while illite-smectite interlayers are completely replaced by illite. The whole-rock and clay mineralogical evolution of the Shahezi Formation is primarily controlled by thermal diagenesis, although paleoenvironmental change may act as a minor contribution. Combined with published data from the Upper Cretaceous in SK-1 cores, we infer that Cretaceous greenhouse climatic and environmental changes left fingerprints on whole-rock and clay mineralogical assemblages and that the Songliao Basin reached a maximum burial depth and a peak of thermal evolution at the end of the Cretaceous.
\end{abstract}

Keywords: Songliao Basin; mineralogical evolution; thermal history; paleoenvironmental evolution

\section{Introduction}

The Songliao Basin in northeastern China is one of the largest and longest-lived terrestrial sedimentary basins in the world [1,2]. The thousands-of-meters thick Cretaceous strata provide valuable material for the study of Earth's greenhouse climate [2]. This basin is also enriched in petroleum and geothermal resources. The Daqing Oilfield, one of the largest oilfields in China, produced $2.4 \times 10^{9} \mathrm{t}$ oil and $1.4 \times 10^{11} \mathrm{~m}^{3}$ gas during the past sixty years [3]. The modern geothermal gradient in northern Songliao Basin ranges from 2.0 to $6.0^{\circ} \mathrm{C} / 100 \mathrm{~m}$, with an average of $4.0^{\circ} \mathrm{C} / 100 \mathrm{~m}$ [4]. The total geothermal resource of hot dry rocks, featured with high temperatures over $150{ }^{\circ} \mathrm{C}$ and located at $3-10 \mathrm{~km}$, is up to $2.2 \times 10^{23} \mathrm{~J}$, approximately equivalent to 7.5 trillion tons of standard coal [4]. Although modern Songliao Basin has a high geothermal gradient and contains rich geothermal resources, the basin's thermal history, which is critical for understanding the evolution history of tectonism, basin filling, and resource formation, has not been well constrained, especially from long and continuous sedimentary records. 
The Continental Scientific Drilling project of Cretaceous Songliao Basin (abbreviated as SK project), under the framework of the International Continental Scientific Drilling Program (ICDP), obtained over 8000-m-long continuous cores from the Triassic basement to the Late Cretaceous $[5,6]$. The long and continuous SK cores are informative for understanding sedimentary, tectonic, and thermal evolution of the basin as well as Cretaceous terrestrial paleoclimatic and paleoenvironmental changes [2,6-10]. Previous studies indicate that, in the Upper Cretaceous cores of the SK, the compositions of whole-rock minerals and clay minerals are mainly controlled by paleoenvironments in sediments shallower than $1000 \mathrm{~m}$ but are primarily influenced by burial diagenesis in sediments deeper than $1000 \mathrm{~m}[7,9]$. Clay mineralogical paleogeothermometer indicates the Upper Cretaceous sediments in the Songliao Basin were buried $\sim 50{ }^{\circ} \mathrm{C}$ higher and $\sim 1000 \mathrm{~m}$ deeper than the present [9]. However, similar constraints from Early Cretaceous strata are still lacking, blurring knowledge of the basin's thermal evolution throughout the Cretaceous period.

In this study, we present whole-rock and clay mineralogical analysis on mudstone, siltstone, and sandstone samples from the 3346-5705 m Shahezi Formation of the SK-2 core, the second stage of the SK project. The controlling factors for mineralogical changes are discussed with special emphasis on their implications on burial temperatures. Combined with a published dataset from the Upper Cretaceous cores, we give a full picture of mineralogical, paleoenvironmental, and thermal evolutions of the Songliao Basin.

\section{Geological Setting}

The Songliao Basin is located between the eastern Pacific plate subduction zone and the northern Mongolia-Okhotsk suture zone and is a large terrestrial basin containing oil and gas deposits in northeast China (Figure 1). It is mainly distributed in three provinces of Heilongjiang, Jilin, and Liaoning in China. It is approximately $800 \mathrm{~km}$ long and $370 \mathrm{~km}$ wide, covering an area of about $26 \times 10^{4} \mathrm{~km}^{2}$ with a shape similar to a rhombus [11]. The north side of the basin is the Lesser Xing'an Range, the east side is the Zhangguangcai Range, the west side is the Greater Xing'an Range, and the south side is connected to the Bohai Bay Basin. Due to the influence of the Pacific plate and the Eurasian plate tectonics, the Songliao Basin's tectonic evolution is divided into four stages, namely a hot uplift and extensional faulting stage, a rift stage, a depression stage, and a tectonic inversion-shrinking fold stage [12]. During the Middle Jurassic to the Early Cretaceous, the uplift of the mantle caused the extensional faulting of crust. Later, the Mongolia-Okhotsk trough closed, which caused a large amount of magmatic activity. A large number of extensional faults formed during the magmatic activity in the basin, indicating the basin was entering the tectonic rift stage, then the Huoshiling Formation and the Shahezi Formation deposited (Figure 2). When the magmatic activity weakened with lithosphere cooling, the basin began to sink and settle. Two lake invasion events occurred during the deposition of the Qingshankou Formation and the Nenjiang Formation. Under the combined action of compress and extension, the basin began to shrink. Facies of river to shore-shallow lake were distributed in the Sifangtai Formation and the Mingshui Formation in the basin (Figure 2) [1]. Areas with different topographical characteristics were formed, such as the central depression zone, the westward dip zone, the eastern uplift zone, and the western uplift zone (Figure 1) [11].

The recently completed ICDP project in the Songliao Basin (SK) obtained nearly continuous sedimentary archives from the basin basement through the latest Cretaceous Mingshui Formation [2,6]. The SK project consists of three phases. Phase 1, the SK-1 drilling project, recovered Upper Cretaceous cores of $\sim 2500 \mathrm{~m}$ with a core recovery ratio of $\sim 95 \%$ from two boreholes, namely SK-1s borehole (deeper) and SK-1n borehole (shallower) (Figure 2) [2,6]. Phase 2, the SK-2 drilling project, recovered a $>4000 \mathrm{~m}$ long core of Lower Cretaceous strata through the Triassic-Permian basement (Figure 2) [6]. Phase 3, the SK-3 drilling project, was completed in February of 2021 and obtained the core of the mid-Cretaceous strata in the Songliao Basin [12]. 


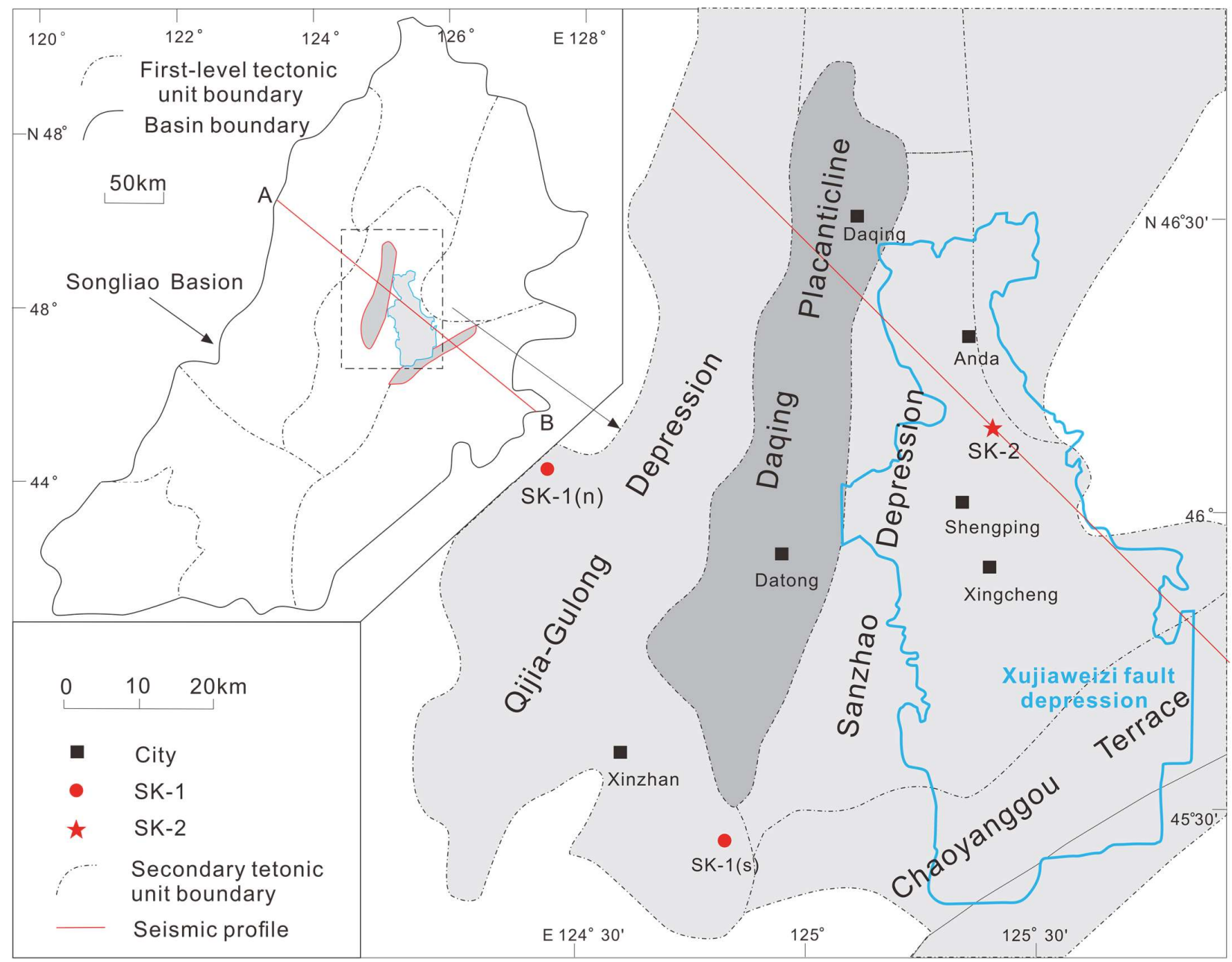

Figure 1. Geological and geographic setting of the Songliao Basin and the SK scientific drillings modified from [12].

The SK-2 scientific borehole is located in the northern part of the Xujiaweizi fault depression and obtained a core section from the Denglouku Formation to the basement with a thickness of $\sim 4200 \mathrm{~m}$ [13-15]. Among the cored strata, the Shahezi Formation developed primarily from lacustrine sediments $[2,16,17]$. Accompanying the activities of the fault depression in the basin, a lake and fan-delta environment was formed during deposition of the Shahezi Formation. It was a set of clastic rock deposits mixed with dark mudstone, coarse sandstone, and conglomerate. Yu et al. (2020) obtained a secondary ion mass spectrometry (SIMS) U-Pb age of $113.9 \pm 0.9 \mathrm{Ma}$ from the $3961 \mathrm{~m}$ tuff layer in the upper part of the Shahezi Formation in SK-2 [17]. An (2018) obtained an inductively coupled plasma mass spectrometry (LA-ICP-MS) clast U-Pb age of $111.13 \pm 0.84 \mathrm{Ma}$ for the sandstone at the top of the Shahezi Formation [18]. Liu et al. (2020) obtained detrital zircon ages from two tuff layers at the bottom of the Shahezi Formation at $5943.19 \mathrm{~m}$ and $5958.6 \mathrm{~m}$. The LA-ICP-MS U-Pb ages of the detrital zircons are $117.9 \pm 1.6 \mathrm{Ma}$ and $118.2 \pm 1.5 \mathrm{Ma}$, respectively, which constrained the sedimentary age of the Shahezi Formation in SK-2 to the Early Cretaceous $[19,20]$. 


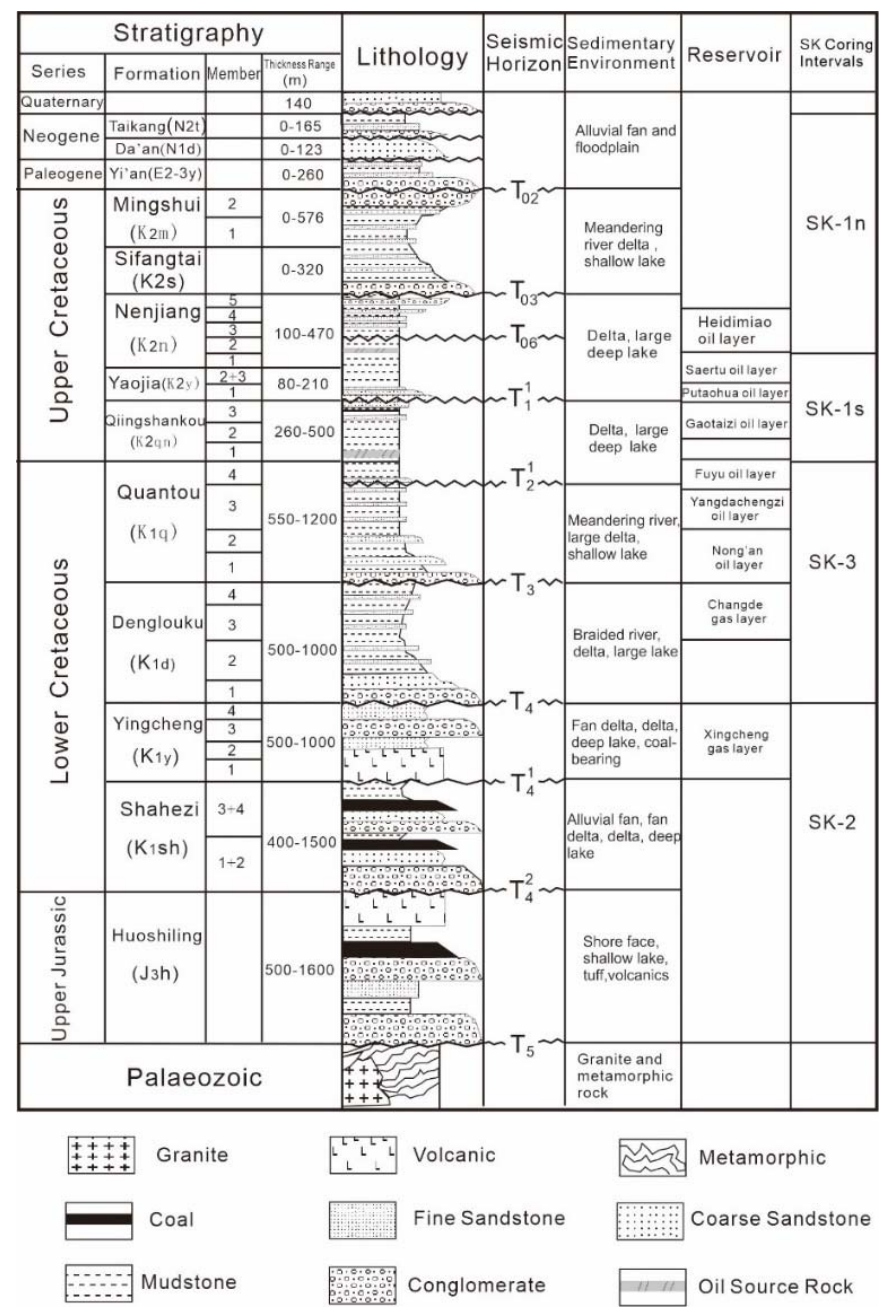

Figure 2. Stratigraphy in the Songliao Basin and coring strategy of the SK scientific drilling projects $[1,2,6]$.

\section{Materials and Methods}

Samples were taken from the Lower Cretaceous Shahezi Formation of the SK-2 core in the depth range of 3346-5705 m. During the drilling of SK-2, the core recovery ratio of the Shahezi Formation was $96 \%$, which ensured the continuity of the core. A total of 72 mudstone, siltstone, and sandstone samples were collected continuously at a $\sim 30 \mathrm{~m}$ sampling interval from the Shahezi Formation.

Whole-rock minerals were studied using X-ray diffraction (XRD). Steps for whole-rock mineral content analysis involved taking a small amount of sample and grinding it to powder. Analytical tests were performed using the PANalytical $X^{\prime}$ Pert PRO diffractometer (PANalytical B.V., Almelo, Netherlands) under the conditions with CuKa radiation and Ni filter under $40 \mathrm{kV}$ voltage, $40 \mathrm{~mA}$ current, and $5-45^{\circ}$ scan angle, specified in the industry standard SY/T 5163-2010, at the Sichuan Southwest Metallurgical \& Geological Testing Technologies Co. Ltd., Chengdu, China. The whole-rock minerals were identified by the characteristic mineral diffraction peaks, for example, quartz $4.26 \AA$ (100), $3.34 \AA$ (101), and $2.45 \AA$ (110), calcite $3.03 \AA$ (104) and $2.28 \AA$ (113), K-feldspar $3.19 \AA$ (131), plagioclase $4.03 \AA$ (201), $3.86 \AA(1 \overline{1} 1)$, etc. The mineral content was calculated as the ratio of the intensity of the diffraction peaks of the two phases when the corundum and the calculated mineral mass fraction were equal, i.e., the K-value method [20].

Clay minerals $(<2 \mu \mathrm{m})$ were studied using X-ray diffraction (XRD) on mounts of clay-sized particles on glass slides [9]. Steps for clay mineral determination consisted of the following: (1) samples were crushed to less than 200 mesh particle size, and clay minerals were extracted by suspension and sedimentation method; (2) tests were performed on 
oriented slices under natural air-drying at room temperature; (3) the naturally oriented tablets were saturated with ethylene glycol vapor at $60^{\circ} \mathrm{C}$ for $8 \mathrm{~h}$; (4) tests were performed with slices after heating at $550{ }^{\circ} \mathrm{C}$ for $2.5 \mathrm{~h}$; (5) calculation was performed of the percentage of each clay mineral using analytical software. Identification of clay minerals was based on the location of the (001) series substrate reflections using MDI JADE software (6.5, Central South University, Hunan, China) according to the method of Moore and Reynolds [21].

Clay mineral identification involved comparing air-dried state $(\mathrm{N})$, glycol-saturated (EG), and heated (T) diffractograms. Illite was identified based on its characteristic peaks at $10 \AA$ (001), $5 \AA$ (002), and $3.33 \AA$ (003), all of which remained unaffected after undergoing glycol saturation. Chlorite was identified on a shift of $14.2 \AA$ peak to the high angle side of $13.8 \AA$ after high temperature treatment at $550{ }^{\circ} \mathrm{C}$, whereas the rest of the identification peaks showed weakening or disappearance [9]. Smectite and illite-smectite interlayer minerals (I/S), which are typically expansive clay minerals, were identified based on the presence of a peak at 16.9-17.1 $\AA$ on EG diffractograms. The presence of smectite was further confirmed by peaks at $8.5 \AA$ (002) and $5.67 \AA$ (003), and, under the T diffractograms, the 16.9-17.1 $\AA$ peak shifted to $10 \AA$ on the high angle side [9]. The illite-smectite interlayer minerals showed that the peak of 10-15.4 $\AA$ in the $\mathrm{N}$ diffractograms shifted to about $17 \AA$ after ethylene glycol treatment and then returned to $10 \AA$ under high temperature conditions. Smectite was distinguished from interlayer minerals by $8.5 \AA$ and $5.67 \AA$ peaks, and disordered and ordered interlayers were distinguished by whether or not the air-drying 10-15.4 A peak shifted to $17 \AA$ after ethylene glycol treatment [20-23].

Semiquantitative estimates of each clay mineral were obtained using the peak areas and heights of the basal reflections of the main clay mineral groups following SY / T 51632010 [20]. The relative abundances of each clay mineral species were estimated mainly

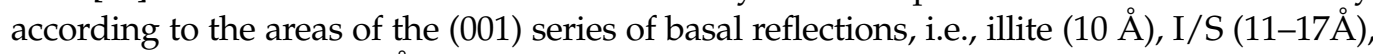
and kaolinite/chlorite ( $7 \AA$ ). The smectite content in illite-smectite interlayer minerals was calculated by two methods-ordered and disordered. The peak at around $17 \AA$ under ethylene glycol conditions divided the interlayer minerals into ordered and disordered [23]. For disordered interlayer minerals, we used methods of Eslinger and Savin [24], Hoffman [25,26] to derive derived $1 / \mathrm{h}$ based on the standard diffraction curves of Reyonlds and Hower $[25,26]$. h was the heights of the $17 \AA$ diffraction peaks, and 1 was the distance from the tip of the $17 \AA$ low-angle side peak to the valley of the peak. The principle of the method is the correspondence between the intensity of the diffraction peaks in the Reyonlds and Hower $[25,26]$ standard curve $17 \AA$ and the layer of smectite content, i.e., $1 / \mathrm{h}=0.39, \mathrm{~S} \%=60 \%$, $1 / \mathrm{h}=0.77, \mathrm{~S} \%=80 \%$ [23-25]. For ordered interlayer minerals, calculation was made by taking characteristic XRD peak positions of the illite-smectite interlayer minerals (001/001, 001/002, 001/003) and their corresponding S\% published by Srodon $[23,26]$.

\section{Results}

The whole-rock minerals of the Shahezi Formation are mainly clay minerals (39.8\%), quartz (31.6\%), and plagioclase (25.2\%), with a small amount of calcite, potassium feldspar, siderite, and pyrite (Figure 3, Table S1). Quartz has diffraction peaks of $4.26 \AA$ (100), $3.34 \AA$ (101), and $2.45 \AA$ (110), calcite has diffraction peaks of $3.03 \AA$ (104) and $2.28 \AA$ (113), and potassium feldspar has a diffraction peak of $3.19 \AA$ (Figure 4 ). With increasing depth, all clay minerals, plagioclase, potassium feldspar, and calcite change at $4500 \mathrm{~m}$. The average contents of clay minerals above $4500 \mathrm{~m}$ and below $4500 \mathrm{~m}$ are $45.8 \%$ and $34.5 \%$ respectively. The contents of potassium feldspar and calcite fluctuate, and the average content increases below $4500 \mathrm{~m}$. The average content of potassium feldspar above $4500 \mathrm{~m}$ is $0.6 \%$, while plagioclase and calcite are $20.5 \%$ and $1.3 \%$, respectively. The average content of potassium feldspar below $4500 \mathrm{~m}$ is $1.5 \%$, plagioclase is $29.2 \%$, and calcite is $3.2 \%$. The contents of quartz, siderite, and pyrite do not change with depth (Figure 3$)$. There is no obvious change with respect to difference in lithology (mudstone, siltstone, sandstone) (Figure 4). 


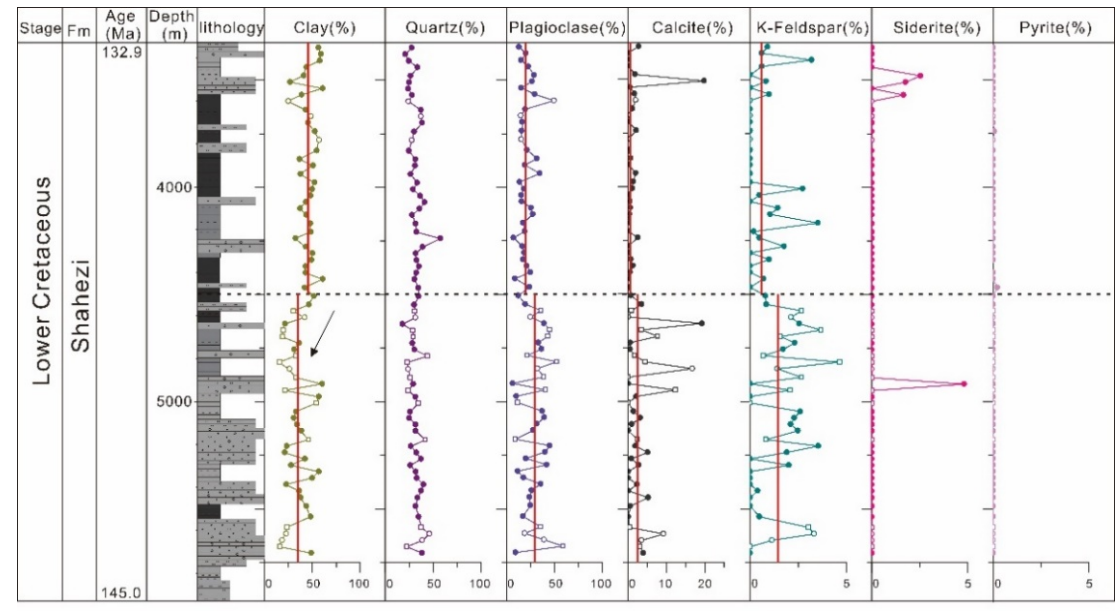

$-\infty$ mudstone $\cdots$ siltstone $\cdots$ sandstone $\infty 0$ conglomerate $\square$ andesite Clay=chlortie+illite+l/s.

Figure 3. The whole-rock mineral content of the Shahezi Formation in SK-2. Solid circles are mudstone samples, hollow circles are sandstone samples, and hollow squares are siltstone samples.
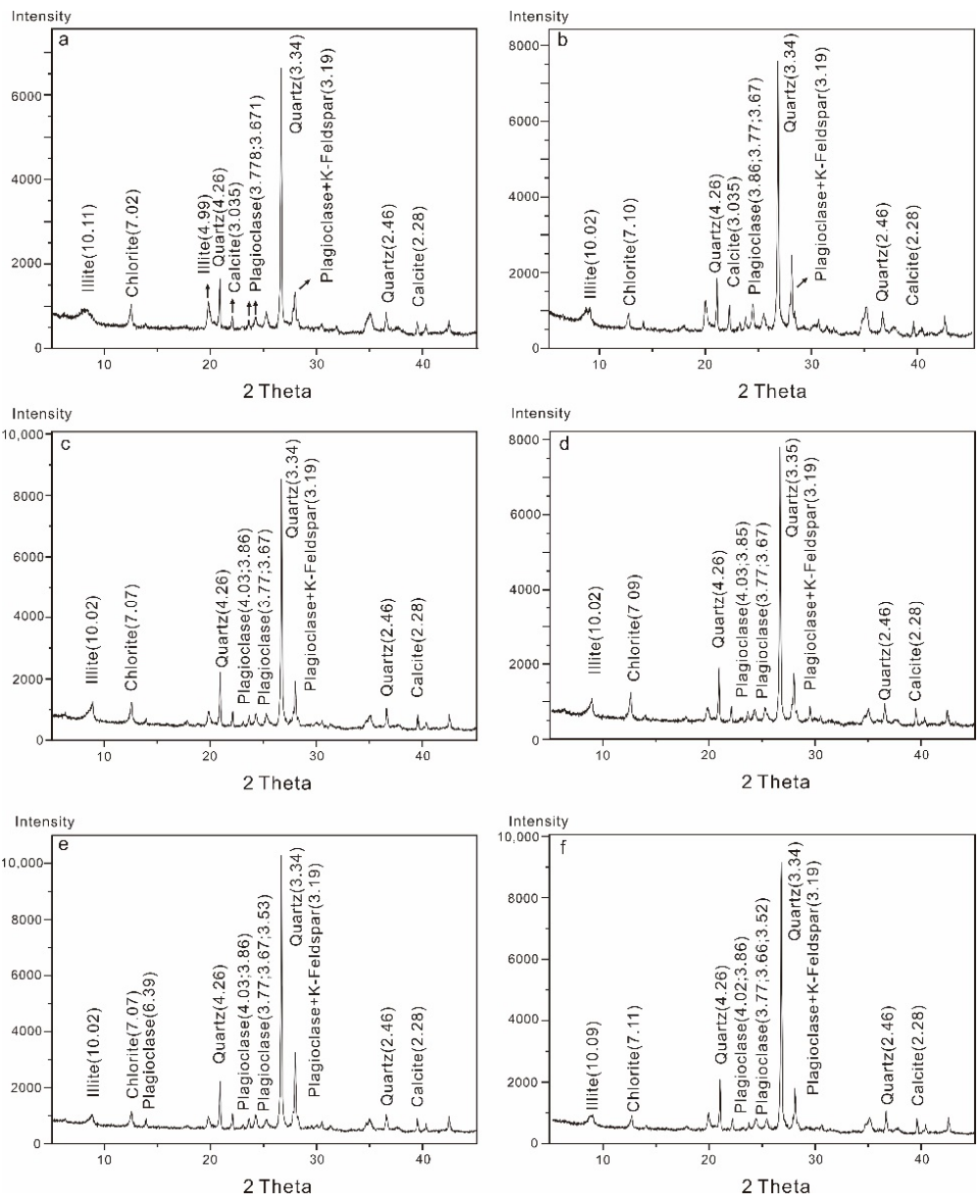

Figure 4. XRD patterns of six typical samples of whole-rock minerals at different depths in the Shahezi mineral of the SK-2. (a) Mudstone sample at $3536 \mathrm{~m}$; (b) mudstone sample at $3826 \mathrm{~m}$; (c) mudstone sample at $4206 \mathrm{~m}$; (d) mudstone sample at $4545 \mathrm{~m}$; (e) mudstone sample at $5045 \mathrm{~m}$; (f) mudstone sample at $5535 \mathrm{~m}$. N: air-dried sample; EG: ethylene glycol saturated sample; T: heated sample.

The clay mineral assemblages of the Shahezi Formation include illite (68\%), chlorite $(15 \%)$, and illite-smectite-ordered interlayer mineral (17\%) (Figure 5, Table S1). Among them, the content of illite continues to increase with the increase of depth above $4500 \mathrm{~m}$. The content of smectite in the ordered interlayer mineral and the interlayer mineral decreases 
with the increase of depth. At shallower depth, the identification peaks of 16.9-17.1 under the EG condition are shown in the XRD pattern. However, there are no identification peaks of $8.5 \AA$ (002) and $5.67 \AA$ (003) of smectite (Figure 6a). As the depth increases, the peak reflection intensity of 16.9-17.1 $\AA$ in the XRD pattern of the EG sheet decreases (Figure $6 b$ ), while the peak reflection intensity of $10 \AA, 5 \AA$, and $3.33 \AA$ increases (Figure 6c). Illite is the main clay mineral in the depths below $4500 \mathrm{~m}$. Illite and chlorite show a mirror trend of changing content, and illite-smectite interlayer minerals disappear completely (Figure 5). In the XRD pattern under EG condition, the identification peaks of 16.9-17.1 A disappear (Figure 6d). The identification peaks of illite are $10 \AA, 5 \AA$, and $3.33 \AA$ (Figure 6e). The identification peaks of chlorite are $7.1 \AA$ and $3.53 \AA$ (Figure $6 f$ ).

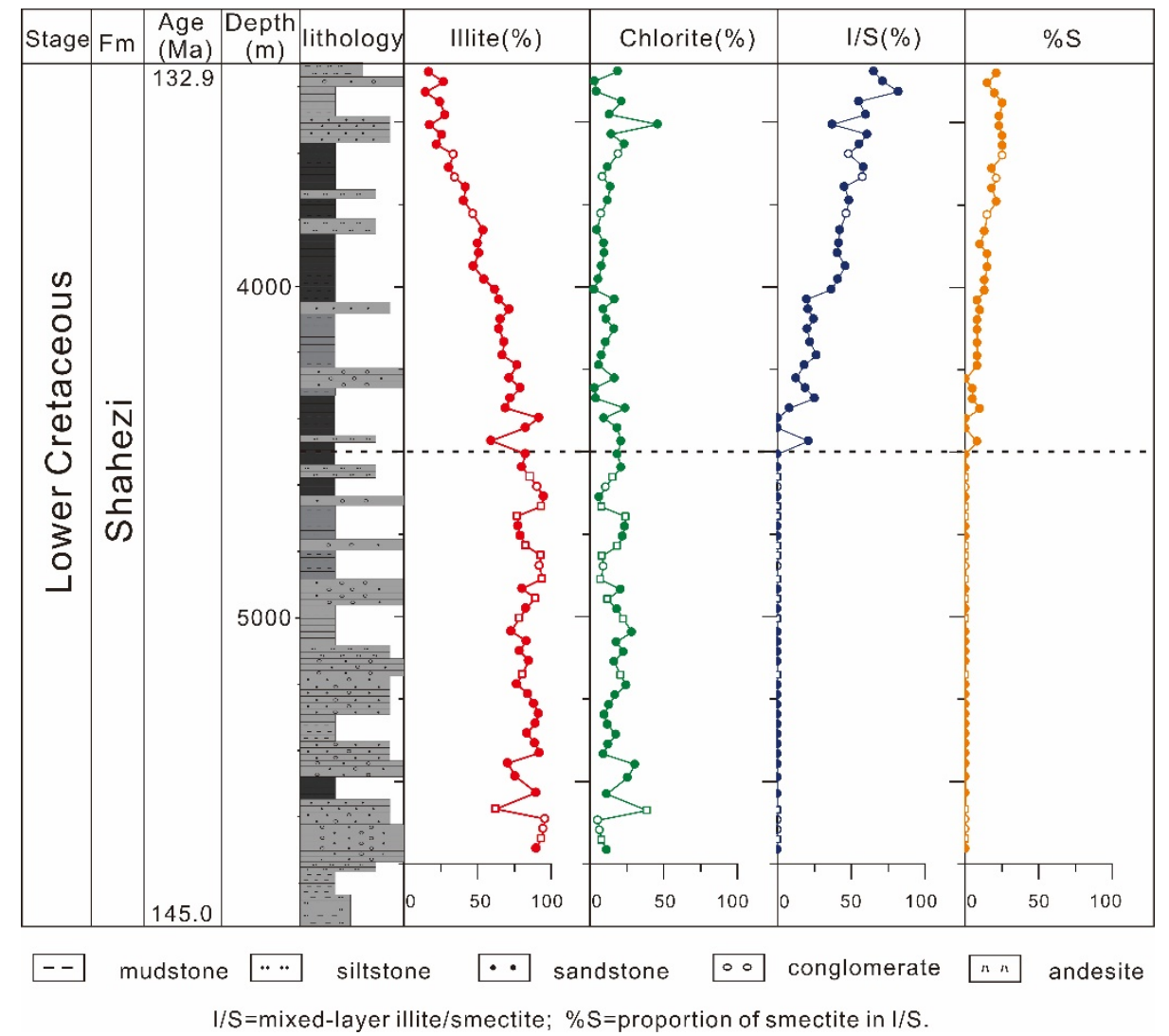

Figure 5. Clay mineral content of Shahezi Formation in SK-2. Solid circles are mudstone samples, hollow circles are sandstone samples, and hollow squares are siltstone samples. 

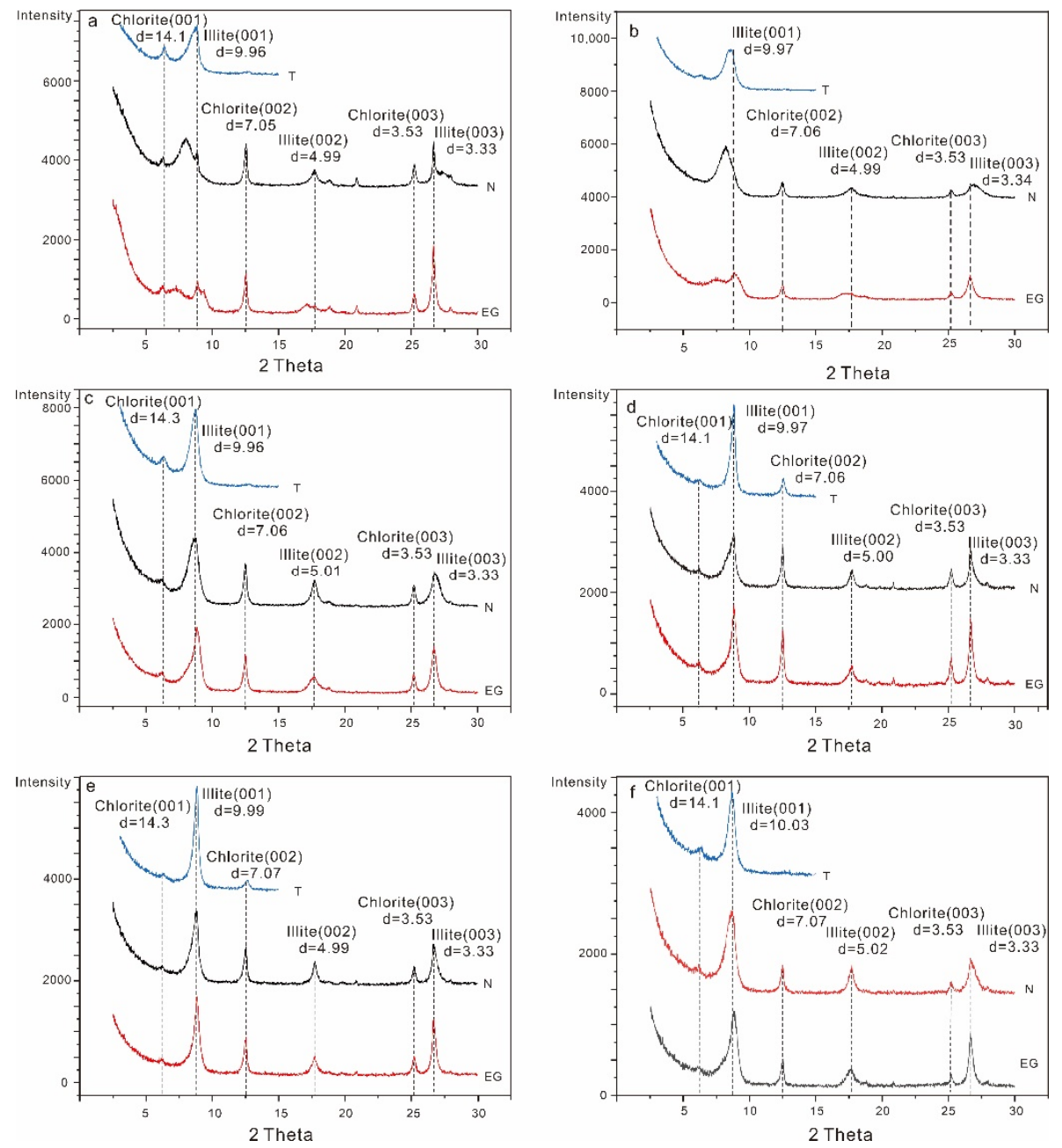

Figure 6. XRD patterns of six typical clay mineral samples at different depths from the Shahezi mineral in SK-2. (a) Mudstone samples at 3436 m; (b) mudstone samples at 3736 m; (c) mudstone samples at $4126 \mathrm{~m}$; (d) mudstone samples at $4545 \mathrm{~m}$; (e) mudstone samples at $4975 \mathrm{~m}$; (f) mudstone samples at $5415 \mathrm{~m}$. N: air-dried sample; EG: ethylene glycol saturated sample; T: heated sample.

\section{Discussion}

Minerals in sedimentary rocks are affected by multiple factors such as source lithology, palaeoclimate, sedimentary environment, and diagenesis. This study discusses the controlling factors for the evolution of whole-rock and clay mineralogy of the Shahezi Formation in SK-2. Combined with the mineralogical data of SK-1, we analyzed the paleoenvironmental evolution and the thermal evolution history of the Songliao Basin.

5.1. Relationship between the Whole-Rock Mineral Composition in the Shahezi Formation and the Sedimentary Environment

In sedimentary processes, bulk mineralogical composition of sediments is controlled by lithology in provenance, climate condition, differentiation in transport and deposition, etc. For example, warmer and wetter climates induce chemical weathering of micas and feldspars, which triggers the formation of clay minerals [27,28]. After sediments get buried, diagenetic processes may alter the original mineralogical composition. For example, the transition from smectite to illite under high temperatures is accompanied by the formation of authigenic quartz [29]. The albitization of plagioclase and potassium feldspar is also a common process in diagenesis, which means the relative content of albite increases with the increase of burial depth [30-32]. 
The Shahezi Formation in SK-2 of the Songliao Basin was deposited in a lacustrine to a fan-delta environment with primary lithologies of sandstone, siltstone, mudstone, and coal seam [33]. Whole-rock mineral X-ray diffraction analysis shows that the Shahezi Formation is dominated by clay minerals, quartz, and plagioclase, while calcite, potassium feldspar, siderite, and pyrite are present in small amounts. At $4500 \mathrm{~m}$, there is a marked change in the content of some minerals (the red lines in Figure 3 indicate the average content at the $4500 \mathrm{~m}$ boundary), with clay minerals increasing from $45.8 \%$ to $34.5 \%$, plagioclase decreasing from $29.2 \%$ to $20.5 \%$, and calcite and potassium feldspar respectively decreasing from $3.2 \%$ and $1.5 \%$ to $1.3 \%$ and $0.6 \%$.

Compaction has a significant impact on the sediments of the Shahezi Formation due to a great burial depth. The impact of compaction is more manifested as chemical compaction, that is, suture contact between clastic grain due to pressure-solution dissolution, secondary quartz and calcite, and other phenomena, which leads to increase of secondary mineral content [33]. As the depth increases, especially across $4500 \mathrm{~m}$, the increase in calcite content may be the result of chemical compaction during diagenesis. However, as the depth increases (especially across $4500 \mathrm{~m}$ ), the clay mineral content increases and the quartz content remains unchanged. The decrease in quartz and plagioclase content is difficult to explain by diagenesis and is more likely to be affected by changes in a paleoenvironment.

The potential source areas around the Songliao Basin include the Greater Xing'an Range, the Lesser Xing'an Mountains, the Zhangguangcai Mountains, and the Jiamusi blocks. An (2018) used the clast grain component and the detrital zircon U-Pb ages to determine the potential provenance of the Shahezi Formation [18]. It is considered that the central area of the Greater Xing'an Mountains provides a stable source for the upper part of the Shahezi Formation [7]. Therefore, change of sediment source is not the main factor that affects the whole-rock mineral evolution of the Shahezi Formation in SK-2.

In continental lake basins, fluctuation of lake level controls the formation of the sequence stratigraphic interface and the distribution of different types of sediments, which is tightly linked to the paleoclimate and the paleoenvironment. Changes in the ratio of precipitation and river inflow versus evaporation cause the lake level to rise and fall, which is accompanied by changes in sedimentary environments [34]. Changes of sedimentary environments further affect the deposition of clastic rocks, the types of clay minerals and other cement minerals, and the abundance of other minerals [34]. Liu [35] and Zhao [36] used the natural gamma logging curve, magnetic susceptibility, and other indicators to reconstruct the lake level changes of the Shahezi Formation. The overall pattern is that the lake level rises slowly, with two rising nodes in the middle and the upper parts of the Shahezi Formation and an obvious sudden change at $4500 \mathrm{~m}$. The magnetic susceptibility and the frequency susceptibility values also have obvious changes within this depth range, indicating that, during the deposition of the Shahezi Formation, basin fault activities, precipitation, and river injection cause the lake level to fluctuate and gradually rise. The lake level reached its maximum in the middle of the Shahezi Formation [35,37]. This is consistent from the perspective of the whole-rock mineral evolution characteristics. With $4500 \mathrm{~m}$ as the interface, the mineral contents of feldspar, plagioclase, and other minerals change significantly, affected by a change in lake level. High and stable lake level above $4500 \mathrm{~m}$ is the reason for more clay minerals and less plagioclase and potassium feldspar deposited in the lake basin.

\subsection{Relationship between Clay Mineral Evolution and Burial Diagenesis}

Clay minerals are sensitive to both depositional paleoenvironment and diagenesis. On one hand, for sedimentary rocks with shallow burial depth and less impact by diagenesis, clay minerals can better reflect environmental and climatic conditions of the sedimentary basin and the source area [38]. On the other hand, as burial depth and temperature gradually increase during diagenetic processes, primary minerals undergo a series of physical and chemical changes $[2,12,15,16]$. For example, smectite transforms into ordered illite-smectite mixed layer and illite [38]. 
The clay mineral assemblage of the Shahezi Formation in SK-2 is dominated by illitesmectite ordered interlayer mineral and illite with a small amount of chlorite (Figure 5). From $3346 \mathrm{~m}$ to $4500 \mathrm{~m}$, as the depth increases, the content of the illite-smectite interlayer decreases, and the illite content increases. Below $4500 \mathrm{~m}$, the illite-smectite interlayer disappears, and the clay mineral assemblage is dominated by illite. This is consistent with the data of other wells in Xujiaweizi Depression below $4500 \mathrm{~m}$ that do not contain the illite-smectite interlayer minerals [36]. Although analyzed samples in this study include mudstone, siltstone, and sandstone, we found no correlation between lithologies and clay mineral assemblages. The change of clay minerals in the Shahezi Formation of SK-2 is considered to be mainly caused by burial diagenesis.

According to previous studies on the clay mineralogy of the Songliao Basin, the smectite in the shallower strata in the Late Cretaceous was mainly formed by the alteration of volcanic rocks around the basin. The illite was mainly formed by the weathering of granite $[11,37]$. As the depth of burial diagenesis increases, smectite loses water when the temperature rises to about $100{ }^{\circ} \mathrm{C}$ and absorbs $\mathrm{K}^{+}$and $\mathrm{Al}^{3+}$ released by the dissolution of mica, feldspar, etc. Then, smectite gradually transforms into illite, and its intermediate product is an interlayered mineral (the content of smectitic layers decreases to form ordered interlayered minerals from disordered interlayers). Si is released during the conversion of montmorillonite to illite, and $\mathrm{Mg}$ and Fe further form chlorite $[39,40]$. As a result of the formation of primary illite as well as the transformation of smectite into illite and chlorite during the later diagenesis, the final clay mineral assemblage appears as illite that persists during burial diagenesis. The abundance of illite and chlorite is greater in places where sediments are buried deeper. The content of smectite decreases with depth until it disappears [35].

There are many factors affecting burial diagenesis, but the main controlling factor is temperature [35]. Therefore, the evolution of clay minerals in the diagenetic process can reflect the thermal evolution history of the basin. For example, in the process of illitization of smectite, disordered interlayer minerals transform into ordered interlayer minerals at $\sim 100{ }^{\circ} \mathrm{C}$. The complete conversion temperature of the ordered interlayer mineral into illite occurs at $\sim 210^{\circ} \mathrm{C}$. The temperature logging curve of SK-2 indicates that temperature is about $160^{\circ} \mathrm{C}$ at $4500 \mathrm{~m}$ today [36,37]. At this depth, interlayer clay minerals are completely transformed into illite, indicating that the basin experiences a maximum temperature of $\sim 210^{\circ} \mathrm{C}$ [38-43]. Evidence such as vitrinite reflectance and temperature measurement of inclusions proves that the ancient geothermal gradient in Songliao Basin is $4.26-4.80^{\circ} \mathrm{C} / 100 \mathrm{~m}[9,44]$. Assuming that this geothermal gradient has been maintained since the Cretaceous, it is inferred that the stratum above the Shahezi Formation has eroded by about $500-1000 \mathrm{~m}$. This is consistent with the conclusion from studies in the north hole of SK-1 and provides new evidence for the restoration of the burial history and the thermal evolution of the Songliao Basin [9].

\subsection{Paleoenvironmental Evolution and Thermal History of the Songliao Basin: Perspective from} Mineralogical Evolution in the SK Cores

The SK cores of the Songliao Basin obtain the most complete and continuous terrestrial strata of the Cretaceous, which provides the theoretical basis for the study of climatic and environmental evolution history of the Cretaceous terrestrial facies on a scale of one million to one hundred thousand years as well as the burial history and the thermal evolution of the Songliao Basin. According to previous studies on the core of SK-1, the SK-1n minerals are dominated by illite and smectite. Illite-smectite-ordered interlayer minerals, kaolinite, and chlorite are enriched in the lower part of the core. SK-1s clay mineral assemblages are illite, illite-smectite-ordered interlayer minerals, smectite, and chlorite $[6,7,9]$. The shallow-buried clay minerals in Nenjiang, Sifangtai, and Mingshui Formations are mainly controlled by the paleoenvironment. The deep-buried clay minerals in Qingshankou, Quantou, and Shahezi Formations are affected by diagenesis $[6,7,9,45]$. The smectite in the mudstones of Nenjiang Formation, Sifangtai Formation, and Mingshui Formation comes from volcanic weathering or palaeosoil transformation in temperate and semi-humid to 
semi-arid climates. The illite mainly comes from erosion of granite, mostly the products of physical weathering and/or weak chemical weathering on crystalline rocks. The chemical index of illite, which represents chemical composition of illitic minerals, is a useful indicator for weathering intensity $[6,9,20,46,47]$. Gao et al. [45] used indicators such as the relative content and ratio of montmorillonite and illite and the illite crystallinity index to reconstruct paleoenvironmental changes and showed that, from the latest Cretaceous through the earliest Paleogene, values of all three clay mineralogical proxies in the Songliao Basin are generally higher during warming intervals than those during cooling intervals. It is concluded that warming caused strengthened moisture delivery from the Pacific, increasing precipitation and intensified chemical weathering, whereas cooling was accompanied by increasing dryness and physical weathering. It was found that, during global warming and cooling events, the corresponding changes in wet and dry climates and the intensity of weathering occurred in the Songliao Basin, which proves that East Asia is sensitive to changes of greenhouse climate. Based on the comprehensive analysis of the whole-rock mineral and other paleoenvironmental indicators of the Shahezi Formation in SK-2, this study reveals that the change of whole-rock mineral is closely related to the changes of lake level, which further shows that the evolution of minerals has an important implication on the study of the Cretaceous greenhouse climate and the changes in sedimentary environments of the continental lake basin.

The clay minerals in the SK-1s Qingshankou Formation and the Quantou Formation are basically illite, illite-smectite-ordered interlayer minerals, smectite, and chlorite, which are mainly controlled by burial diagenesis. In SK-1s, the highest burial temperature for $20 \%$ smectite in the illite-smectite-ordered interlayer in $1915 \mathrm{~m}$ is $140{ }^{\circ} \mathrm{C}$, with the modern drilling temperature of $95^{\circ} \mathrm{C}$. The highest burial temperature for $25 \%$ smectite in interlayer minerals at the $1500 \mathrm{~m}$ is $125^{\circ} \mathrm{C}$, with the temperature of $75{ }^{\circ} \mathrm{C}$. It is inferred that the maximum burial depth was about $1000 \mathrm{~m}$ deeper than the current one. The temperature was about $50{ }^{\circ} \mathrm{C}$ higher than the current one [9]. The clay minerals in the SK-2 Shahezi Formation are dominated by illite-smectite-ordered interlayer minerals and illite, with a small amount of chlorite. Minerals in the $4500 \mathrm{~m}$ interlayer are completely converted into illite. The maximum burial temperature is $210^{\circ} \mathrm{C}$, and the current drilling temperature is $160{ }^{\circ} \mathrm{C}$. The maximum burial depth and the temperature inferred from clay minerals in the Shahezi Formation are consistent with the previous studies on the Qingshankou Formation and the Quantou Formation.

The tectonic evolution of the Songliao Basin indicates that the subsidence of the basin ended with the deposition of the upper part of the Nenjiang Formation. Due to the subduction of the Pacific plate, the basin experienced structural inversion and denudation [1]. At the end of the deposition of the upper Nenjiang Formation, the regional uplift caused about $500 \mathrm{~m}$ of denudation in the central depression zone [35]. After the Mingshui Formation stopped depositing, strong structural movement folded the stratum, causing denudation of about $1000 \mathrm{~m}$ in the central depression zone [48]. The inferred maximum burial temperature and maximum burial depth of the clay minerals in the Shahezi Formation are consistent with previous studies, indicating that the subsidence continued from the Early Cretaceous to the end of the Cretaceous, and the maximum burial depth occurred at the top of the Mingshui Formation. This provides a clearer understanding of the evolution history and is of significance for guiding thermal exploration and oil-gas exploration.

In the mode of sedimentary organic matter evolution, when the vitrinite reflectance (Ro) is larger than 2.0 and the temperature is higher than $200{ }^{\circ} \mathrm{C}$, the organic matter fraction gradually changes from oil to gas [49-51]. Cui et al. [15] demonstrated that the vitrinite reflectance (Ro) at 3900-4500 m depth in the Shahezi Formation of SK-2 in the Songliao Basin is 2.3-2.5, which is consistent with the present results showing that the maximum burial temperature of the Shahezi Formation of SK-2 at $4500 \mathrm{~m}$ is $210{ }^{\circ} \mathrm{C}$, and the interbedded illite-smectite minerals are completely converted to illite [15]. These results indicate that natural gas exploitation in the Shahezi Formation of the Songliao Basin is of priority in the near future. 


\section{Conclusions}

The whole-rock and clay mineralogy of the SK-2 Shahezi Formation in the Songliao Basin was analyzed from 3346-5705 m. The relationship between mineralogical evolution and the thermal evolution of the basin as well as paleoenvironmental change was studied. The whole-rock minerals in the Shahezi Formation mainly include clay minerals as well as small amounts of calcite, potassium feldspar, and siderite. Clay minerals include illite, chlorite, and illite-smectite interlayer minerals, with relative content varying with depth. Both the wholerock and the clay mineral compositions change at $4500 \mathrm{~m}$. Above $4500 \mathrm{~m}$, the clay minerals are dominated by illite-smectite-ordered interlayer minerals and illite. Below $4500 \mathrm{~m}$, there is more plagioclase, potassium feldspar, and calcite, whereas the interbedded illite-smectite minerals are completely transformed into illite. Evolution of whole-rock minerals is mainly affected by the environment, but the evolution of clay minerals is affected by diagenesis. Combined with other data from the SK cores, the maximum burial depth and the maximum burial temperature of the Songliao Basin in the Late Cretaceous are inferred, which provides a certain reference for thermal evolution history, paleoenvironmental evolution, and deep petroleum exploration of the Songliao Basin.

Supplementary Materials: The following are available online at https:/ / www.mdpi.com/article/10 $.3390 / \min 11101101 / \mathrm{s} 1$, Table S1: Whole rock minerals and clay minerals data.

Author Contributions: Conceptualization, T.D., Y.G.; data curation, T.D.; formal analysis, T.D.; investigation, T.D.; methodology, T.D., Y.G.; resources, Y.G.; supervision, Y.G.; visualization, T.D.; Q.Y., Y.L., L.N., Y.C., writing original draft, T.D.; writing-review and editing, Y.G., H.H., and X.T. All authors have read and agreed to the published version of the manuscript.

Funding: This study was supported by the National Natural Science Foundation of China (41790452), the Key Scientific and Technological Project of RIPED (2021ycq01) and the China Geological Survey Program (DD20190502).

Data Availability Statement: The data from whole-rock and clay mineralogical proxies used in this study are available from the supplement.

Acknowledgments: We deeply thank Qiang Peng for accessing the analytical facilities at Sichuan Southwest Metallurgical \& Geological Testing Technologies Co. Ltd., China.

Conflicts of Interest: The authors declare no conflict of interest.

\section{References}

1. Feng, Z.; Jia, C.; Xie, X.; Zhang, S.; Feng, Z.; Cross, T. Tectonostratigraphic units and stratigraphic sequences of the nonmarine Songliao basin, northeast China. Basin Res. 2010, 22, 79-95. [CrossRef]

2. Wang, C.; Feng, Z.; Zhang, L.; Huang, Y.; Cao, K.; Wang, P.; Zhao, B. Cretaceous paleogeography and paleoclimate and the setting of SKI borehole sites in Songliao Basin, Northeast China. Palaeogeogr. Palaeoclimatol. Palaeoecol. 2013, 385, 17-30. [CrossRef]

3. Wang, G.J.; Wang, F.L.; Zhao, B.; Sun, G.X.; Meng, Q.A.; Wang, Y.Z.; Liang, J.P.; Fang, Y.J. E\&P situation and development strategy of Daqing Oilfield Company. China Pet. Explor. 2021, 26, 55-73. [CrossRef]

4. Wu, X.X. Research on Geothermal Resources of Dry Heat Rock in Northern Songliao Basin. Ph.D. Thesis, Northeast Petroleum University, Daqing, China, 2014.

5. Wang, C.S. Late Cretaceous climate change records from the Songliao Basin, East Asia and the Western North American Seaway, American continent. Sci. Tech. Inn. Her. 2016, 13, 175-176.

6. Gao, Y.; Wang, C.; Wang, P.; Gao, Y.; Huang, Y.; Zou, C. Progress on Continental Scientific Drilling Project of Cretaceous Songliao Basin (SK-1 and SK-2). Science Bull. 2019, 64, 73-75. [CrossRef]

7. Gao, Y.; Wang, C.; Liu, Z.; Zhao, B.; Zhang, X. Clay mineralogy of the middle Mingshui Formation (upper Campanian to lower Maastrichtian) from the SKIn borehole in the Songliao Basin, NE China: Implications for palaeoclimate and provenance. Palaeogeogr. Palaeoclimatol. Palaeoecol. 2013, 385, 162-170. [CrossRef]

8. Gao, Y.; Ibarra, D.E.; Wang, C.; Caves, J.K.; Chamberlain, C.P.; Graham, S.A.; Wu, H. Mid-latitude terrestrial climate of East Asia linked to global climate in the Late. Cretac. Geol. 2015, 43, 287-290. [CrossRef]

9. Gao, Y.; Wang, C.; Liu, Z.; Du, X.; Ibarra, D.E. Diagenetic and Paleoenvironmental Controls on Late Cretaceous Clay Minerals in the Songliao Basin, Northeast China. Clays Clay Miner. 2015, 63, 469-484. [CrossRef]

10. Xi, D.; Wan, X.; Li, G.; Li, G. Cretaceous integrative stratigraphy and timescale of China. Sci. China Earth Sci. 2019, 62, 256-286. [CrossRef] 
11. Gao, R.F.; Zhang, Q.L.; Wang, L.S.; Xie, G.A.; Xu, S.Y.; Chen, J.; Wang, X.Y. Tectonic Evolution of the Songliao Basin and Tectonic Regime Transformation in Eastern China. Geol. Rev. 2010, 2, 180-195.

12. Wang, P.J.; Liu, H.B.; Ren, Y.G.; Wan, X.Q.; Wang, S.X.; Qu, X.J.; Meng, Q.A.; Huang, Y.J.; Huang, Q.H.; Gao, Y.F.; et al. Site selection for the "Songke 2 well" in the Cretaceous continental scientific drilling in the Songliao Basin. Front. Earth Sci. 2017, 24, 216-228.

13. Wang, C.; Gao, Y.; Ibarra, D.; Wu, H.; Wang, P. An Unbroken Record of Climate During the Age of Dinosaurs. EOS 2021, 102. [CrossRef]

14. Hou, H.S.; Wang, C.S.; Zhang, J.D.; Ma, F.; Fu, W.; Wang, J.P.; Huang, Y.J.; Zhou, C.C.; Gao, Y.F.; Gao, Y. Progress of Geoscientific Research on Deep Continental Scientific Drilling in Songliao Basin. Geol. Bull. China 2018, 45, 7-23.

15. Cui, J.; Zhu, R.; Wang, C.; Gao, Y.; Li, S.; Kang, L. Source/reservoir characteristics and shale gas "sweet spot" interval in Shahezi mudstone of Well SKII in Songliao Basin, NE China. Arab. J. Geosci. 2020, 13, 514. [CrossRef]

16. Feng, Z.; Wang, C.; Graham, S.; Koeberl, C.; Dong, H.; Huang, Y.; Gao, Y. Continental Scientific Drilling Project of Cretaceous Songliao Basin: Scientific objectives and drilling technology. Palaeogeogr. Palaeoclimatol. Palaeoecol. 2013, 385, 6-16. [CrossRef]

17. Yu, Z.; He, H.; Deng, C.; Lu, K.; Li, Q. New SIMS U-Pb geochronology for the Shahezi Formation from CCSD-SK-IIe borehole in the Songliao Basin, NE China. Sci. Bull. 2020, 65, 1049-1051. [CrossRef]

18. An, Z.D. Sedimentary Record and Source Analysis of the Upper Part of the Early Cretaceous Shahezi Formation in the Songliao Basin. Master's Thesis, China University of Geosciences, Beijing, China, 2018.

19. Liu, H.; Wang, P.; Gao, Y. New data from ICDP borehole SK2 and its constraint on the beginning of the Lower Cretaceous Shahezi Formation in the Songliao Basin, NE China. Sci. Bull. 2021, 66, 411-413. [CrossRef]

20. Method for the X-ray Diffraction Analysis of Clay Minerals and Common Non-Clay Minerals in Sedimentary Rocks, SY/T 5163-2010; Industry Standard; Legal Rule or Regulation, Oil and Gas Industry Standards of the People's Republic of China: Beijng, China, 2010.

21. Moore, D.M.; Reynolds, R.C. X-Ray Diffraction and the Identification and Analysis of Clay Minerals. Clay Miner. 1999, 34, 210-211.

22. Chamley, H. Clay Sedimentology; Springer: Berlin, Germany, 1989; p. 623.

23. Zhao, X.Y.; Zhang, Y.Y. Clay Minerals and Analysis of Clay Minerals; China Ocean Press: Beijing, China, $1990 ;$ pp. $106-141$.

24. Eslinger, E.V.; Savin, S.M. Mineralogy and oxygen isotope geochemistry of the hydrothermally altered rocks of the OhakiBroadlands, New Zealand, geothermal area. Am. J. Sci. 1973, 273, 240-267. [CrossRef]

25. Reynolds, R.C. The Nature of Interlayering in Mixed-Layer Illite-Montmorillonites. Clays Clay Miner. 1970, 18, 25-36. [CrossRef]

26. Srodon, J. X-ray powder differaction identification of illitic materials. Clays Clay Miner. 1984, 18, 25-36.

27. Peltonen, C.; Marcussen, O.; Bjorlykke, K.; Jahren, J. Clay mineral diagenesis and quartz cementation in mudstones: The effects of smectite to illite reaction on rock properties. Mar. Pet. Geol. 2009, 26, 887-898. [CrossRef]

28. Ye, C.; Yang, Y.; Fang, X.; Hong, H.; Zhang, W.; Yang, R.; Song, B.; Zhang, Z. Mineralogical and Geochemical Discrimination of the Occurrence and Genesis of Palygorskite in Eocene Sediments on the Northeastern Tibetan Plateau. Geochem. Geophys. Geosyst. 2018, 19, 567-581. [CrossRef]

29. Zhao, X.Y. Clay minerals and oil and gas. Xinjiang Pet. Geol. 2009, 30, 533-536.

30. Chen, X.; Zhon, J.H.; Yuan, J.; Wang, H.A.; Wang, J.X. Characteristics and hydrocarbon significance of clay minerals in deep clastic reservoirs in the Boonan Depression. Acta Petrol. Sin. 2009, 30, 201-207.

31. Ji, Y.L.; Hu, G.M.; Zhang, S.W.; Zhao, J.Q. Mineral and Geochemical Methods in Sedimentary Sequence Interface Studies. J. Tongji Med. Univ. 2004, 4, 455-460.

32. Bellanca, A.; Yang, X.H. Identification of lake level variations in the Miocene lacustrine unit of the Madrid Basin, Spain, using phase analysis, isotope geochemistry and clay mineral evidence. J. Gems Gemmol. 1993, 3, 61-66.

33. He, H.J. Analysis of the relationship between lake level changes and geochemical characteristics-Take Qianjiang Depression as an example. J. Xinjiang Petr. Inst. 2003, 4, 18-21.

34. Huang, H.; Gao, Y.; Ma, C.; Jones, M.M.; Zeeden, C.; Ibarra, D.E.; Wu, H.; Wang, C. Organic carbon burial is paced by a 173-ka obliquity cycle in the middle to high latitudes. Sci. Adv. 2021, 7, eabf9489. [CrossRef] [PubMed]

35. Liu, J.W. Chemical Stratigraphic Framework Establishment and Climatic Cyclic Analysis of the Upper Part of the Shahezi Formation in Songliao Basin, China; China University of Geosciences: Beijing, China, 2020.

36. Zhang, X.; Li, S.; Yin, T. Terrestrial expression of the Cretaceous greenhouse regime and its relationship withOAE1a: Evidence from the Jiaolai Basin, Eastern China. Geol. J. 2021, 56, 525-546. [CrossRef]

37. Qu, X.J.; Yang, L.W.; Xue, X. Scientific drilling of SK-2 in the Cretaceous continent of Songliao Basin: Prediction of bottomhole temperature and formation pressure. Front. Earth Sci. 2017, 24, 257-264. [CrossRef]

38. Wang, X.X. Study of Clay Minerals in the Songliao Basin; Heilongiiang Science and Technology Press: Harbin, China, 1990.

39. Ren, F.L. Clay Minerals and Clay Rocks; Geological Publishing House: Beijing, China, 1992.

40. Liang, J.H.; Sun, B.L. Clay Mineral Studies in Mudstone Diagenesis: Contributions to Geology and Mineral. Resour. Res. 2016, 31, 543-549.

41. Osborn, S.G.; Duffield, L.T.; Elliott, W.C.; Wampler, J.M.; Elmore, R.D.; Engel, M.H. The timing of diagenesis and thermal maturation of the Cretaceous Marias River Shale, Disturbed Belt, Montana. Clays Clay Miner. 2014, 62, 112-125. [CrossRef] 
42. Srodon, J.; Clauer, N.; Huff, W.; Dudek, T.; Banas, M. K-Ar dating of the Lower Palaeozoic K-bentonites from the Baltic Basin and the Baltic Shield: Implications for the role of temperature and time in the illitization of smectite. Clay Miner. 2009, 44, 361-387. [CrossRef]

43. Wang, C.; Feng, Z.; Wu, H.; Wang, P.; Kong, F.; Feng, Z.; Ren, Y.; Yang, G.; Wan, X.; Huang, Y.; et al. View Correspondence. Preliminary Achievement of the Chinese Cretaceous Continental Scientific Drilling Project-SK-I. Acta Geol. Sin. 2008, 82, 9-20.

44. Ren, Z.L.; Xiao, D.M.; Chi, Y.L. Paleothermal recovery in the Songliao Basin. Daqing Petr. Geol. Dev. 2001, 20, 13-15.

45. Gao, Y.; Gao, Y.F.; Ibarra, D.E.; Du, X.J.; Dong, T.; Liu, Z.F.; Wang, C.S. Clay mineralogical evidence for mid-latitude terrestrial climate change from the latest Cretaceous through the earliest Paleogene in the Songliao Basin, NE China. Cretac. Res. 2021, 124, 104827. [CrossRef]

46. Petschick, R.; Kuhn, G.; Gingele, F. Clay mineral distribution in surface sedimentsof the South Atlantic: Sources, transport, and relation to oceanography. Mar. Geol. 1996, 130, 203e229. [CrossRef]

47. Liu, Z.; Wang, H.; Hantoro, W.S.; Sathiamurthy, E.; Colin, C.; Zhao, Y.; Li, J. Climatic and tectonic controls on chemical weathering in tropical SoutheastAsia (Malay Peninsula, Borneo, and Sumatra). Chem. Geol. 2012, 291, 1e12. [CrossRef]

48. Xiang, C.F.; Feng, Z.Q.; Pang, X.Q.; Heyong, W.U.; Junhong, L.I. Late stage thermal history of the Songliao Basin and its tectonic implications: Evidence from apatite fission track (AFT) analyses. Sci. China 2007, 50, 1479-1487. [CrossRef]

49. Zeng, G.S.; Xu, M.H. Petroleum Geochemistry; Petroleum Industry Press: Beijing, China, 1990.

50. Lv, D.; Song, Y.; Shi, L.Q.; Wang, Z.L.; Cong, P.Z.; Tomvan Loon, A.J. The complex transgression and regression history of the northern margin of the Palaeogene Tarim Sea (NW China), and implications for potential hydrocarbon occurrences. Mar. Pet. Geol. 2020, 112, 104041. [CrossRef]

51. Lv, D.; Li, Z.X.; Wang, D.D.; Lin, Y.; Lin, H.Y.; Wang, P.L. Sedimentary model of coal and shale in the Paleogene Lijiaya Formation of the Huangxian Basin: Insight from Petrological and Geochemical Characteristics of Coal and Shale. Energy Fuels 2019, 33, 10442-10456. [CrossRef] 